\title{
HBV Reactivation after Autologous Hematopoietic Stem-cell Transplantation in a HBsAg-negative Patient
}

MS Dal ${ }^{1}$, A Doğan $^{2}$, A Karakuş $^{1} \mathrm{~T} \mathrm{Dal}^{3}, \mathrm{M} \mathrm{Kaya}^{4}, \mathrm{O}^{\mathrm{Ayy}} \mathrm{K}_{\mathrm{ld}} \mathrm{z}^{1}$

\begin{abstract}
A 58-year-old female patient whose Serological test results were HBsAg negative and HBsAb positive, diagnosed with Multiple myeloma. Autologous hematopoietic stem-cell transplantation was subsequently performed after induction chemotherapy. 1 year later the patient was diagnosed as HBV reactivation and was started on lamivudine oral therapy. HBsAg is negative and HBsAb is positive in patients scheduled for chemotherapy, HBV DNA levels should still be investigated. Patients in the risk group should be started on prophylactic antiviral therapy. Lamivudine can be used in treatment in patients who have not received prophylactic antiviral therapy who develop HBV reactivation during or after chemotherapy.
\end{abstract}

Keywords: Reactivation HBV, multiple myeloma, chemotherapy

From: ${ }^{1}$ Department of Hematology, ${ }^{2}$ Department of Internal Medicine, ${ }^{3}$ Department of Microbiology, and ${ }^{4}$ Department of Gastroenterology, Faculty of Medicine, Dicle University, Diyarbakır, Turkey

Correspendence: Dr. A Dogan, Department of Internal Medicine, Faculty of Medicine, Dicle University, Diyarbakır, Turkey. Fax:+904122488523, e-mail: dr.a.dogan@hotmail.com 


\section{INTRODUCTION}

Hepatitis B virus (HBV) is a significant, global health problem. It is one of the most common infection agents. It infects approximately 350 million people worldwide, and 1 million people die from infection-related complications annually (1). HBV remains latent in the form of covalently closed circular DNA (cccDNA) in the hepatocyte cytosol although Hepatitis B surface antibody (HBsAb) positive is present in serum following resolution of acute HBV infection, (2). The virus may be reactivated following chemotherapy or in immunodepression (3). HBV reactivation is frequently seen in Hepatitis B surface antigen (HBsAg) positive patients after chemotherapy, and antiviral prophylaxis is recommended before chemotherapy in these patients (4). There is no consensus in the literature on a strategy for HBsAg negative patients, however. Reactivated lymphomas are frequently reported, particularly following chemotherapy regimens involving rituximab and steroid (5), although there are few reports in the literature concerning patients with multiple myeloma. We described a case of an HBsAg negative and HBsAb positive patient with multiple myeloma with HBV reactivation following a VAD (vincristine, doxorubicin, dexamethasone) regimen.

\section{CASE REPORT}

A 58-year-old female patient had presented to our hospital 4 years previously with lethargy and lower back ache. Multiple myeloma was diagnosed on the basis of tests (IgA- $\square \square \square$ type; stage II in both the Durie-Salmon and international staging systems). The patient had no additional disease. Tests before chemotherapy revealed HBsAg negative and HBsAb positive (HBsAb; $72.7 \mathrm{IU} / \mathrm{mL}$ ). Alanine transaminase (ALT) was $20 \mathrm{U} / \mathrm{L}$, aspartate transaminase (AST): $20 \mathrm{U} / \mathrm{L}$, total bilirubin: $0.3 \mathrm{mg} / \mathrm{dl}$, albumin: $3 \mathrm{~g} / \mathrm{dl}$ and platelet count: 213,000 K/mcL. Partial response was achieved following 3 cycles of VAD induction therapy. Autologous 
hematopoietic stem-cell transplantation (HSCT) was subsequently performed. No complications occurred and the patient was discharged 10 days after HSCT. Approximately 1 year after HSCT the patient re-presented to our hospital with lethargy, abdominal pain, nausea and bilateral yellowing of the sclerae. Scleral icterus and tenderness in the right upper quadrant were present at physical examination. Laboratory findings were hemoglobin: 13.4 g/dL, platelet count: $167,000 \mathrm{~K} / \mathrm{mcL}$; white blood cell count: $6,340 \mathrm{~mm}^{3}$, ALT: $814 \mathrm{U} / \mathrm{L} \mathrm{U} / \mathrm{L}$, AST: $1115 \mathrm{U} / \mathrm{L}$, total bilirubin: $11.3 \mathrm{mg} / \mathrm{dl}$, direct bilirubin: $8.6 \mathrm{mg} / \mathrm{dl}$ indirect bilirubin: 2.7 $\mathrm{mg} / \mathrm{dl}$, albümin: $2 \mathrm{~g} / \mathrm{dL}$, and international normalized ratio (INR): 1.05. Serological test results were negative for HBsAb, Hepatitis B e antibody (HBeAb), Hepatitis B core antibody (HBcAb) IgM, Hepatitis A virüs antibody (HAV Ab) IgM, Hepatitis E virüs antibody (HEV Ab) IgM, and positive for HBsAg, Hepatitis B e antigen (HBeAg), HBcAb IgG The serum HBV DNA level was 170,000,000 IU/mL. Toxoplasma, rubella, cytomegalovirus and herpes Simplex Virus viral serology was investigated, but proved negative. There was no pathology at abdominal sonography. On the basis of these findings, the case was diagnosed as HBV reactivation following VAD + HSCT. The patient was started on oral lamivudine at 150 $\mathrm{mg}$ /day. Bilirubin and other hepatic enzymes were monitored. One week after start of treatment the symptoms resolved and hepatic enzymes began to decrease, although bilirubin elevation persisted for some time further. On the $14^{\text {th }}$ day of hospitalization, values decreased to ALT: $500 \mathrm{U} / \mathrm{L}, \mathrm{AST}: 400 \mathrm{U} / \mathrm{L}$, total bilirubin: $8.7 \mathrm{mg} / \mathrm{dL}$ and direct bilirubin: $6.4 \mathrm{mg} / \mathrm{dl}$. The patient was discharged, but lamivudine therapy was maintained. Hepatic enzymes were within normal ranges at 4-month follow-up. The patient is still under monitoring by the hematology clinic, and her condition is stable. 
Table-1. Changes in the liver function panel after lamivudine treatment.

\begin{tabular}{lllllllll}
\hline & 04.04 .20 & 10.04 .20 & 14.04 .20 & 16.05 .20 & 20.05 .20 & 22.05 .20 & 21.08 .2 & \\
& 13 & 13 & 13 & 13 & 13 & 13 & 013 & \\
$\mathrm{AL}$ & 854 & 380 & 400 & 421 & 150 & 120 & 28 & $\mathrm{U} / \mathrm{L}$ \\
$\mathrm{T}$ & & & & & & & & \\
$\mathrm{AS}$ & 1115 & 421 & 589 & 270 & 70 & 80 & 33 & $\mathrm{U} / \mathrm{L}$ \\
$\mathrm{T}$ & & & & & & & & \\
$\mathrm{T} . \mathrm{Bi}$ & 11,3 & 13,1 & 8,7 & 2,2 & 1,3 & 1,1 & 0,6 & $\mathrm{mg} / \mathrm{dl}$ \\
$\mathrm{l}$ & & & & & & & & \\
\hline
\end{tabular}

T.Bil: total bilirubin, ALT: Alanine transaminase, AST: Aspartate transaminase

\section{ISCUSSION AND CONCLUSION}

Healing and positive HBsAb and negative HBsAg occur after acute HBV infection has been experienced. However, HBV cannot be entirely eliminated from the body, but remains latent in the form of cccDNA in the hepatocyte cytosol (2). The virus may be reactivated following chemotherapy or in immunodepression. This also indicated that the virus is not completely eliminated (3). HBV reaction is most prevalent in hematological malignancies for which hematopoietic stem-cell transplantation is performed. (6) Our patient had multiple myeloma and had received HSCT .

HBV reactivation is a known phenomenon following immunosuppressive therapy in patients with positive HBsAg (4) but is rare in those with positive HBsAb and negative HBsAg. HBV DNA polymerase of the virus that escapes immune system control with immunosuppressive therapy is activated and the virus replicates. The replicated virus infects the hepatocytes, leading to an increase in HBV DNA and HBsAg levels and a decrease in HBsAb titer. Reverse seroconversion of HBsAg occurs (7). Once chemotherapy is completed, 
however, immunosuppressive status disappears and immunity destructs infected hepatocytes. This results in clinical hepatitis. Advanced hepatocyte injury may result in fulminant liver failure $(8,14)$. In our case, too, reverse seroconversion occurred following VAD chemotherapy despite HBsAg negativity and HBsAb positivity. Transaminase and bilirubin levels increased and clinical hepatitis was present. The patient was cured with therapy and without liver failure developing.

Various risk factors in terms of development of $\mathrm{HBV}$ reactivation during and following chemotherapy have been reported. These include young age, male gender, HBsAg positivity and HBeAg positivity, chemotherapy regimens involving steroid and/or rituximab and elevated pre-treatment ALT and HBV levels (9). A high pre-chemotherapy HBV DNA level $(>100,000$ copies $/ \mathrm{mL})$ is the most important risk factor (10). Our case was different due to the absence of any risk factors apart from receipt of steroid. HBV DNA had not been investigated in our case due to pre-chemotherapy transaminase levels being normal and HBsAg negativity, but it was investigated following an elevation in hepatic enzymes and HBsAg positivity. Identification of these risk factors in patients scheduled for chemotherapy will be useful in terms of preventing HBV reactivation. The question of antiviral prophylaxis will therefore arise before immunosuppressive treatment (4).

HBV reactivation can lead to fatal complications such as fulminant hepatic failure in immunosuppressive conditions or during chemotherapy. This is particularly important when chemotherapy is to be given to patients in regions where HBV is endemic (11). Hui et al. (12) determined HBV reactivation after chemotherapy in eight out of 244 patients with lymphoma. Four of these eight were HBsAb positive before chemotherapy. This shows that HBsAb positivity reduces the risk of $\mathrm{HBV}$ reactivation. Our patient being HBsAb positive and HBV reactivation occurring following chemotherapy supports this thesis. Again in that study, HBV DNA was found to have increased more than 100-fold despite ALT in serum being normal 
before chemotherapy in the 8 individuals who developed HBV reactivation. This also shows that latent $\mathrm{HBV}$ infection lies behind HBV reactivation (13). HBV DNA was not investigated in our case due to pre-chemotherapy HBsAb positivity and HBsAg negativity and ALT being normal. It was therefore unclear whether our patient had hidden HBV infection.

Clark et al. (15) used $2 \times 150 \mathrm{mg} /$ day lamivudine in the treatment of reactive fulminant HBV infection in a patient with non-Hodgkin's lymphoma. Improvement occurred in clinical symptoms and liver function tests after a few days and HBV DNA was reported negative within the first 12 weeks. In the light of similar cases in the literature, we started our patient on lamivudine $150 \mathrm{mg}$ /day oral therapy. Symptoms improved after a few days, and hepatic enzymes returned to normal ranges after 4 months of lamivudine therapy.

In conclusion, even if ALT is normal, HBsAg is negative and HBsAb is positive in patients scheduled for chemotherapy, HBV DNA levels should still be investigated due to the possibility of fulminant liver failure and death (11). Patients in the risk group should be started on prophylactic antiviral therapy. Lamivudine can be used in treatment in patients who have not received prophylactic antiviral therapy who develop HBV reactivation during or after chemotherapy. 


\section{EFERENCES}

1. Lavanchy D. Hepatitis B virüs epidemiology, disease burden, treatment, and current and emerging prevention and control measures. J Viral Hepat 2004; T 97-07.

2. Werle-Lapostalle B, Bowden S, Locarnini S, Wursthorn K, Petersen J, Lau G, Trepo C, Marcellin P, Goodman Z, Delaney WE 4th,Xiong S, Brosgart CL, Chen SS, Gibbs CS, Zoulim F. Gastroenterelogy.2004;1 26: 1750-1758

3. Yim HJ, Lok AS. Natural history of chronic hepatitis B virus infection: what we knew in 1981 and what we know in 2005. Hepatology 2006: 43: 173-81

4. Lok AS, McMahon BJ. Chronic hepatitis B. Hepatology 2007; 45: 507-39.

5. Dervite I, Hober D, Morel P. Acutehepatitis B in a patient with antibodies to hepatitis B surface antigen who was receiving rituximab. N Engl J Med. 2001; 344:68-9.

6. Lau GK. Liang R, Chiu EK, Lee CK, Lam SK.. Hepatic events after bone marrow transplantation in patients with hepatitis B infection: a case controlled study. Bone Marrow Transplant.1997; 8:795-9

7. Rossi G. Prophylaxis with lamivudine of hepatitisB virüs reactivation in chronic $\mathrm{Hbs}$ Ag carriers with hemato-oncological neoplasias treated with chemotherapy. Leuk Lymphoma 2003; 44: 759066.

8. Lau GK, He ML, Fong DY, Bartholomeusz A, Au WY, Lie AK, Locarnini S, Liang R.. Preemptiveuse of lamivudin ereduces hepatitis B exacerbation after allogeneic hematopoietic cell transplantation. Hepatology 2002; B702-9.

9. Yeo W, Zee B, Zhong S, Chan PK, Wong WL, Ho WM, Lam KC, Johnson PJ. Comprehensive analysis of risk factors as sociating with Hepatitis B virüs reactivation in cancer patients under going cytotoxic chemotherapy. Br J Cancer 200 ;90: 1306-11.

10. Lau GK, Leung YH, Fang DY, Au WY, Kwong YL, Lie A, Hou JL, Wen YM, Nanj A, Liang R.. High hepatitis B virus (HBV) DNA viral load as the most important risk 
factor for HBV reactivation in patients positive for HBV surface antigen under going autologous hematopoietic cell transplantation. Blood. 2002; 99: 2324-30.

11. Chung SM, Sohn JH, Kim TY, Yoo KD, Ahn YW, Bae JH, Jeon YC, Choi JH.. Fulminant hepatic failure with hepatitis B virüs reactivation after rituximab treatment in a patient with resolved hepatitis B. Korean J Gastroenterol 2010; 55: 266-9.

12. Hui CK, Sun J, Au WY, Lie AK, Yueng YH. Occult hepatitis B enfection in hematopoietic stemcel donors in a hepatitis B virüs endemic area. J Hepatol 2005; 42: $813-9$.

13. Gastroenterelogy Turkish edition 2006; 2: 228

14. Nakamura Y, Motokura T, Fujita A. Severe hepatitis related to chemotherapy in hepatitis B virus carriers with hematologic malignancies. Cancer 1996; B 2210014505

15. Clark FL, Drummond MW, Chambers S, Chapman BA, Patton WN. Successful treatment with lamivudine for fulminant reactivated hepatitis B infection following intensive therapy for high grade non-Hodgkin's lymphoma. Ann Oncol 1998; 9: 385-7 